\title{
Developing a Participatory Approach to Learning*
}

\author{
Maija Pihlainen
}

\begin{abstract}
* An earlier version of this paper was presented at the Eighth Annual Conference of the Hong Kong Educational Research Association. While the author takes full responsibility for the views expressed here, appreciation and thanks are due to the administration and staff of the School of the Nations who provided inspiration and stimulating ideas that made this paper possible.
\end{abstract}

\begin{abstract}
Beginning with a survey of Bahá'í writings and of emerging Bahá'í approaches to education, the article charts the Macau-based School of the Nations' philosophy of education and considers its implications for the school's curriculum development process. The article then proposes that the cooperative approach to education offers a potential instructional model within which Bahá'í principles and ideals, with their emphasis on moral education, participation, cooperation, and consultation, could be effectively implemented. Finally, the article discusses the school's tentative experiments with this model and the steps taken to begin the model's systematic implementation. The successful continuation of the project, the article suggests, will largely depend on the school's ability to overcome the constraints imposed by the dominant competitive attitudes and practices and to gain acceptance of the value of a participatory and cooperative approach.
\end{abstract}

$\mathrm{I}_{\mathrm{n}}^{\mathrm{n}}$ n a letter to Bahá'í institutions in 1989, the International Teaching Centre at the Bahá'í World Centre identified a number of elements that had made the greatest contribution to the success of so-called institutes, i.e., special educational activities developed for the members of the Bahá'í community for the purpose of their spiritual empowerment. One of the elements credited was the use of participatory methods.

This call for the adoption of a participatory approach to learning, as opposed to teacher-centered methods, captured the interest of the School of the Nations Macau - a fairly new international school currently developing a bilingual multicultural program for kindergarten, primary, and secondary students. ${ }^{1}$ The school's aims are to foster global awareness and an appreciation for the diversity of the human family. Inspired by the statement that "it is only when student learn to become active agents of their own learning, rather than passive listeners that the desired attitudes toward service are born and develop” (International Teaching Centre, 1989 letter), the school's administration agreed to initiate program intended to promote a deeper understanding of what constitutes participatory approach to learning and of how such an approach could be integrated into the school's daily activities.

As background to the search for solutions based on current educational theory and practice, it is necessary to begin with a description of the school's aspirations. The first part of this article, therefore, outlines the school's educational philosophy, followed by a discussion of the concepts of participation and consultation. The second part of the article surveys such aspects of cooperative education (a movement rapidly gaining ground in the United States and elsewhere) as seem to offer an instructional model compatible with the school's objectives. Finally, part three of the article describes the school's efforts to begin a process of participation at all levels of its activities and examines current and future concerns of the school.

\section{Philosophy of Education at the School of the Nations}

While still relying on instructional materials from various international sources, the school is, in consultation with a worldwide network of Bahá'í educators, in the process of establishing its own curriculum and developing materials and methods that would accord more closely with an educational philosophy inspired by the teachings of the Bahá'í Faith. The vision presented here reflects an understanding of these teachings that has evolved as a result of many consultations concerning the school's development. Through further study and contemplation of Bahá'í principles and ideals and their continual interplay with educational theory and practice, new understandings will, no doubt, emerge to expand and sharpen this vision. 


\section{The Nature of Human Reality}

At the heart of the school's educational philosophy is the Bahá'í concept of the nature of human beings. According to this view, human reality has two dimensions: the physical and the spiritual, that is, the body and the soul. It is the soul, with its multiple capacities such as the intellect, emotions, and the will, that distinguishes humans from animals and makes them "the most noble of beings" ('Abdu'l-Bahá, Some Answered Questions 235). In an infant, these spiritual capacities exist as potential to be fully realized through the process of education. The body is essentially perceived as an instrument that enables the soul to manifest its spiritual realities in the world of matter. Therefore, "Man — the true man —is soul, not body ('Abdu'l-Bahá, Paris Talks 85). Consequently, the primary goal in life is to develop spiritual qualities, which are viewed as more fundamental than the physical qualities. It is further understood that the soul is capable of infinite progress ('Abdu'l-Bahá, Some Answered Questions 231, 237) and, therefore, the more one strives the greater will be one’s development (Bahá’u’lláh, Gleanings 81-82).

\section{The Purpose of Education}

Such an understanding of the nature of human reality has profound implications for education, which, the Bahá'í writings explain, is of three kinds: material, human, and spiritual. Material education is concerned with the development and well-being of the body. Human education deals with social order and civilization, including such spheres of human activity as government and administration, economy and trade, industry and agriculture, and sciences, arts and crafts. Important as material and human education are, it is spiritual education-the acquisition of spiritual qualities and moral values - that is perceived as true education (cf. 'Abdu'l-Bahá, Some Answered Questions 7).

Without spiritual education, human beings would succumb to the demands of their physical nature, whereas spiritual education enables them to discipline their material inclinations, to be guided by their intellect and moral judgment, and thus gain maximum control over their own lives and destinies. As a result of this process, "The spirit, or human soul," which is described as "the rider,' will be in charge of "the body," which "is only the steed" ('Abdu’l-Bahá Promulgation 416).

Fundamentally, people "need to know who they are, to what purpose they exist and how they should act towards one another; and, once they know the answers to these questions they need to be helped to gradually apply these answers to everyday behaviour" (Universal House of Justice, quoted in Vick, Social an Economic Development 123). It is, therefore, the foremost role of education enable children to attain self-knowledge, to understand their relationship to other and society, to become aware of their purpose in life, and to gain such knowledge and skills that will empower them to fulfill their potential and to contribute their share to the building of an “ever-advancing civilization” (cf. Bahá'u’lláh Gleanings 215; Universal House of Justice, “To the Peoples” 24).

\section{Major Emphasis on Moral Education}

Thus, while the school strives for academic excellence, its sole emphasis is not on the development of the student's intellectual abilities, in the narrow sense o material knowledge and critical thinking skills, but rather on the balanced grow of the whole person and most particularly of what is known as moral character "the true criterion of humanity" ('Abdu'l-Bahá, Promulgation 427). ${ }^{2}$ In the Bahá'í view, a firm foundation for this growth and development must be laid in early childhood ('Abdu'l-Bahá, Selections 137). The school's moral education program which is based on the universal moral values promoted by all major religions an reaffirmed and restated for this age in the writings of the Bahá'í Faith, cannot focus on the purely cognitive aspects of morality. Its main emphasis must be in providing the students with opportunities to develop and exercise moral qualities and thus through direct experience and practice, to translate "abstract principles into concrete realities ..." (Jordan, Becoming Your True Self 16).

The manifold personal and social qualities and attitudes that need to cultivated include love and affection; kindness and courtesy; generosity and hospitality; honesty and sincerity; truthfulness and trustworthiness; modesty and humility; fairness and justice; diligence, patience, and perseverance; obedience and respect for authority; and an attitude of service and self-sacrifice. Such qualities and attitudes, combined with an understanding of one's role in society and the desire to perform "deeds and actions that will be conducive to the highest good of mankind" (letter on behalf of Shoghi Effendi, quoted in "Living the Life" 2), are seen as fundamental to the progress and well-being of both individual and society. This latter aspect of education gains even greater significance in light of the view that "it is chiefly service to humanity and dedication to the unification of mankind that unlock individual capacity and release creative powers latent in human nature" (Bahá'í International Task Force on Education, "Learning in a Whole World" 4). 


\section{Fostering Global Awareness}

With humanity's accelerating move towards a global community and the imminent realization of a new world order, the socialization role of the school faces a new challenge - that of producing world citizens who see "the whole world. . . as one single country, all the nations as one nation, all men as belonging to one race” ('Abdu'l-Bahá, Paris Talks 131). It is not, however, enough to foster an awareness of the underlying unity and interdependence of the world. Learning the concept of world citizenship-which, the Bahá'ís believe, should be included as part of the standard education of every child (Universal House of Justice, "To the Peoples" 14)—also implies that the students acquire knowledge, skills, values, and attitudes that prepare them for life in a global society and enable them to assume their rights and responsibilities as citizens of the world.

\section{Release of Human Potential}

While placing priority on moral education, the school aspires to "excellence in all things" and sees that its role is to empower each student to achieve his or her personal best, which, the Bahá'í writings explain, varies from child to child as the innate qualities of human beings differ in kind and degree. It is not possible for education to alter this inner human essence, nor can it change inherited physical qualities ('Abdu'l-Bahá, Selections 131-32; Some Answered Questions 212-15; and quoted in "Bahá'í Education" 258). What education can do is to uncover and release each person's unique, wide set of potentialities and facilitate maximum growth and development of these potentialities for the benefit of both the individual and society. ${ }^{3}$

Foremost among these potentialities is the human intellect, which is perceived as a spiritual capacity of the soul rather than a purely physical function of the brain. With its powers of rational thought, understanding, memory, imagination, and intuition, human intellect is valued as "the supreme gift of God to man" ('Abdu'l-Bahá, Foundations 60), a gift that "giveth man the power to discern the truth in all things, leadeth him to that which is right, an helpeth him to discover the secrets of creation” (Bahá’u'lláh, Gleanings 194).

In addressing the whole human being, education must also be concerned with a person's feelings and emotions so that these are mastered rather than the masters. While children need to learn to experience and express such noble sentiments as love, compassion, joy, happiness, and gratitude, they also need to learn how to control the destructive forces of anger, hatred, envy, and the like. This process entails the need for training them to recognize their own emotion experiences and motivations and to develop sensitivity to the feelings of others. It is of utmost importance to train children to love ('Abdu'l-Bahá, Selection 134), "for love includeth every excellence of humankind” and "causeth every soul to go forward” ('Abdu'l-Bahá, Selections 66). Furthermore, "Until love takes possession of the heart no other divine bounty can be revealed in it” ('Abdu'l-Bahá, Bahá'í World Faith 218). Love is thus the foundation on which effective moral education can be built.

A further aspect that requires special attention is the strengthening of the will, for "all that which ye potentially possess can. . . be manifested only as a result of your own volition” (Bahá'u'lláh, Gleanings 149). Thus, one of the goals is for children to become self-determinate and self-directed so that they will eventually be able to assume responsibility for their own learning and development. This striving, Bahá'ís believe, is a lifelong process, for "human perfections are endless” ('Abdu'l-Bahá, Some Answered Questions 230). Therefore, "you cannot find a being so perfect that you cannot imagine a superior one” ('Abdu’l-Bahá, Some Answered Questions 230).

\section{Enhanced Motivation}

It is the Bahá'í view that one’s desire for "acquisition of excellence” ('Abdu'l-Bahá, quoted in "Bahá'í Education” 263) is aroused as one becomes increasingly aware of the nobility inherent in human reality, of the possibilities latent in human nature, and of the responsibilities one has towards self and society. A clear sense of one's identity and purpose in life enables one to set realistic goals and challenge oneself to capacity. The motivation to strive and excel is further enhanced by the development of a moral attitude towards study and work. While children should learn "in play, in amusement” ('Abdu'l-Bahá, quoted in "Bahá'í Education” 310), they should at the same time be guided to "guard against idleness and sloth" (Bahá'u'lláh, Tablets 138), "to exert themselves to the utmost" (Bahá'u'lláh, quoted in "Bahá'í Education" 249), to "spare no efforts," to acquire "the will to strive and endure," to have "high aims," and "learn to be of powerful resolve and firm of purpose in all things." They should not be allowed to "jest and trifle, but earnestly advance unto their goals, so that in every situation they will be found resolute and firm” (“Abdu’l-Bahá, quoted in "Bahá'í Education” 253, 283). The belief that "all effort and exertion put forth by man from the fullness of his heart is worship, if it is prompted by the highest motives and the will to do service to humanity” ('Abdu'l-Bahá, Paris Talks 176-77) gives new meaning to work and elevates it from the level of drudgery to a source of happiness and fulfillment. Such intrinsic motivation transcends the desire for good grades and test scores, creates a thirst for knowledge, and, together with the moral qualities of perseverance and willingness 
to work hard, enables the students to commit intense effort to the learning task and to the development of their own unique potential.

\section{Acquisition of Knowledge, Music, Arts, and Crafts}

“The first attribute of perfection is learning and the cultural attainments of the mind ..." ('Abdu'l-Bahá, Secret 35). Acquisition of all branches of knowledge, and of music, arts, and crafts, is therefore held in high regard. Knowledge, however, is not concerned with mere facts and figures; rather, it is attainment of a true understanding of the laws and mysteries of the universe, including those pertaining to the nature and purpose of an individual human being and of society. Thus, the areas proposed for study are many and varied, including religion and philosophy, human civilization, government and administration, languages and history, social and natural sciences, and technology. In effect, the students should be given "the advantage of every useful kind of knowledge" and be able to "share in every new and rare and wondrous craft and art” ('Abdu'l-Bahá, Selections 129). They should also be encouraged to develop an understanding of "the important problems and complex needs of the time” ('Abdu'l-Bahá, Secret 109). All learning should "result in advantage to man” (Bahá'u’lláh, Tablets 168) and bring important benefits to society ('Abdu'l-Bahá, Secret 105-6). Consequently, emphasis is placed on the relationship between theoretical knowledge and its practical applications. Since "it is the duty of the children to acquire knowledge of the arts and sciences and to learn a trade or a profession whereby they, in turn, can earn their living and support their families" (Universal House of Justice, Wellspring 95), the school intends to integrate traditional academic knowledge with both practical experience and vocational training. Thus, at an early age, the students will be helped to discover their natural inclinations and talents, enabled to be of service to others, and provided with skills that are appropriate to life in contemporary society (cf. Waite, A Charter for Bahá'í Schools 13-14).

Furthermore, it is of utmost importance to nurture and encourage the children's aesthetic potential and to attract them to the beauty in literature, visual arts, crafts, and music - all of which have a great effect on the human spirit. This is particularly true of music, described in the writings as "a ladder by which souls may ascend to the realm on high" (Bahá'u'lláh, quoted in Lights of Guidance 410). Thus, the door is opened to the metaphysical aspects of knowledge, to be obtained through the powers of inner vision and intuition, in other words as a result of contemplation or meditation. According to the Bahá'í view, it is the "faculty of meditation" that helps "unfold the secrets of things-in- themselves" and "brings forth from the invisible plane the sciences and arts." Through this faculty, "affairs of which man knew nothing are unfolded before his view” ('Abdu’l-Bahá, Paris Talks 175).

\section{An Environment of Unity and Encouragement}

It is a Bahá'í understanding that a child's growth must proceed in an organic manner. In other words, learning must be nurtured and guided, but not forced. In Bahá'í references to the education of children, words such as foster, rear, nurse, guide, counsel, and encourage abound. "The instruction of these children," the Bahá'í writings explain, "is even as the work of a loving gardener ... ('Abdu'l-Bahá, quoted in "Bahá'í Education” 266), who should train each child "according to capacity" ('Abdu'l-Bahá, Promulgation 108). Through the process of nurturance, the students become aware of their identity and abilities, and they are empowered to take on the responsibility for their personal transformation. This transformation is, however, to be achieved within the context of society, which "will react on the character of the individual” (Shoghi Effendi, quoted in Rúhíyyih Rabbani, Priceless Pearl 161) and, thus, influence its formation. Because of the significance of the social environment for an individual's growth and development, it is essential, Bahá'ís believe, to provide children with an educational climate that is based on spiritual and moral values.

\section{Building a Sense of Unity}

The atmosphere that the School of the Nations aspires to create among its students, teachers, administrators, parents, and the community at large is best summed up in the word unity, which is the foundation for achieving "unlimited result” ('Abdu'l-Bahá, Foundations 66). A key aspect of the Bahá'í concept of unity is "an unshakeable consciousness of the oneness of mankind ... (Universal House of Justice, "To the Peoples" 16). In an international, multicultural school, it is of central importance to create this consciousness, as it frees the students, teachers, and parents from the destructive influence of all forms of prejudice and bridges the gap between different ages, races, cultures, nationalities, religions, occupations, and ranks. Special attention needs to be paid to bringing about gender equality, with no sex stereotyping in the classroom or on the playground. In keeping with this principle, the same educational opportunities are offered to boys and girls, who follow the same curriculum of study ('Abdu'l-Bahá, Promulgation 175). Ultimately, all human relations within the school community should reflect fellowship and harmony, agreement and reciprocity, equity and equality to such a degree that each and every one would have a sense of belonging to "the circle of intimate friends” (“Abdu’l-Bahá, quoted in "Bahá'í Education” 293). 


\section{Appreciation of Unity in Diversity}

Unity springs, on the one hand, from the recognition of similarities and commonalities, whereas "love and unity come hard when ye fix your gaze on otherness" ('Abdu'l-Bahá, Selections 24). On the other hand, there must also be a genuine appreciation of the diverse talents and characteristics of every human being. Such appreciation entails an unconditional positive regard for each individual and an acceptance of the unique contribution that each is able to make, for "difference reinforceth harmony, diversity strengtheneth love, and multiplicity is the greatest factor for coordination” ('Abdu'l-Bahá, Selections 291). One of the most important harmonizing principles is one's profound conviction in the innate nobility and worth of every human being, "the noblest and most perfect of all created things" (Bahá'u’lláh, Kitáb-i-Íqán 102-3); this is the source of genuine love and respect for self and others.

\section{Development of Critical Reflection and Inquiry}

The Bahá'í concept of independent investigation of reality challenges the school to provide an environment that encourages individual initiative and creativity, expands consciousness, cultivates "the use of the mind" ('Abdu'lBahá, quoted in "Bahá'í Education" 265), and educates "intelligence and thought in such a way that they may attain complete development ... (“'Abdu’l-Bahá, quoted in "Bahá'í Education” 256). The Bahá'í writings emphatically state that "investigation of reality by another will not do for us" ('Abdu'l-Bahá, Foundations 76-77). By this is meant that we are not "intended to see through the eyes of another, hear through another's ears nor comprehend with another's brain," know through another's knowledge, nor rely on the opinion of others; we must depend on our own reason and judgment ('Abdu'l-Bahá, Foundations 76). We are urged to discover things for ourselves, evaluate our own perceptions, thoroughly weigh all information before adopting it, and adhere to the outcome of our own investigations. We are warned that an attitude of uncritical acceptance will, in effect, submerge us in ignorance ('Abdu’l-Bahá, Foundations 76).

Consequently, the school is challenged to develop instructional methods that foster the attitude of experimentation and discovery, stimulate the ability for independent thought and investigation, and enable the students to reason and deliberate, to express their views and understandings, and to apply that which is taught and learned to real-life situations. Thus, the emphasis is not only on what is learned but also, and even more importantly, on how it is learned.

For this aim to succeed, there is a need for an atmosphere of freedom and tolerance that allows students to be fully engaged in the learning task, encourages them to take risks, and trains them to assume responsibility for their decisions and choices. In this manner, the students acquire personally meaningful knowledge arid develop their own view of the world rather than passively absorbing the views and opinions of others.

\section{Discipline and Order}

For students to feel secure and happy, the school must be not only a place o freedom but also "a place of utmost discipline and order ....” ('Abdu'l-Bahá Selections 137). Freedom, it is believed, can only exist within boundaries derives from the established moral values and from mutually agreed behavioral norms that respect the rights of others. The purpose of such boundaries is to "free us to thrive (Universal House of Justice, Individual Rights 8). Discipline and order are ideally achieved through self-control and through the willing acceptance of the moral principles, and respect and obedience to those in authority, in other words through "the subordination of the individual will to that of society” (Shoghi Effendi, quoted in Universal House of Justice, Individual Rights 20).

The Bahá'í writings emphasize that the establishment of order depends on justice (Bahá'u'lláh, Epistle 2829). The Writings further explain that "justice hath a mighty force at its command," which is "none other than reward and punishment for the deeds of men" (Bahá'u’lláh, Tablets 164). Justice means "giving what is deserved" ('Abdu'l-Bahá, Some Answered Questions 232). The ability to administer justice calls for certain characteristics, such as fairness, impartiality, objectivity, detachment, wisdom, and moderation.

In this context, as an element reflecting the overall school climate, a few words need to be said about guidance on how to remedy and control unacceptable and unruly student behavior. According to Bahá'í thought, "good character must be taught” ('Abdu'l-Bahá, Selections 136). Although reward and punishment are accepted as the two pillars of order (Bahá'u'lláh, Tablets 66), it is emphasized that "love and kindness have far greater influence than punishment upon the improvement of human character" (letter on behalf of Shoghi Effendi, quoted in "Bahá'í Education” 300-301). Praise and reward that are deserved have their place in education ('Abdu'l-Bahá, Selection 135-36; Bahá'í World 9: 543). As to children with "complicated personalities, they "need very wise handling" (letter of behalf of Shoghi Effendi, quoted in "Bahá'í Education" 307) and must be trained "gently and patiently" and the behavior "regulated" and "controlled" (letter on behalf of Shoghi Effendi quoted in "Bahá'í Education" 303). The teacher is advised to use "admonition, "explanation," and "good counsel” (see Bahá'u'lláh, quoted in 
"Bahá'í Education” 247) before resorting to punitive measures (cf. Shoghi Effendi quoted in "Bahá'í Education” 300). ". . . means based on reason, even a slight verbal chastisement should this be necessary," are acceptable. "It is not, however," the Writings state, "permissible to strike a child, or vilify him, for the child's character will be totally perverted if he be subjected to blows or verbal abuse” ('Abdu'l-Bahá, Selections 125). The ultimate aim is to "prevent the development of any behaviour that would be worthy of blame” ('Abdu'l-Bahá, Selections 125) and for the child to grow in such a way that "the commission of an evil deed" would be "in itself the harshest punishment of all ...." ('Abdu'l-Bahá, quoted in "Bahá'í Education” 263). It is upheld that "by punitive measures," "the desired aim cannot be properly achieved” ('Abdu'l-Bahá, quoted in "Bahá'í Education” 263). "To look always at the good and not at the bad” ('Abdu'l-Bahá, quoted in Esslemont, Bahá'u'lláh and the New Era 83) is advice that should be applied to most situations in education.

These thoughts indicate the direction a Bahá'í school should take in devising its disciplinary practices, within an overall climate of love, affection, acceptance, encouragement, freedom, and justice. When the school is also filled with joy, the results will be even greater, for joy, the Bahá'í writings state, has the power to impart strength and vitality, sharpen the intellect, and improve understanding ('Abdu'l-Bahá, Paris Talks 109). With such a positive climate, the school would be well equipped to provide "the basic intellectual and spiritual tools necessary for continued growth” (Hatcher and Martin, The Bahá'í Faith 100).

\section{Participation by All}

For Bahá'ís, universal participation is both a principle and a goal (Bahá'í International Community, A Survey 8). One's active involvement in the life of the community, identification with its aspirations and undertakings, willingness to assume one's share of responsibility and fulfill one's unique role are essential elements in personal growth and development. Such an attitude of participation, rather than one of isolation and alienation, is a "source of power and vitality" (Universal House of Justice, Wellspring 38) and therefore a cornerstone in the advancement of a group or a community. Participation by all engenders unity of thought, purpose, and action, and makes possible the attainment of common goals. It enables all to work together, to encourage and support one another, and to coordinate efforts for the good of all (cf. Universal House of Justice, Wellspring 37ff.). This principle of universal participation makes a vital impact on all aspects of the life of a Bahá'í school. As it is an attitude that needs to be learned, it must also, somehow, be included in the school's instructional program.

\section{Openness in the Communication and Decision-making Processes}

In keeping with the principle of universal participation, everyone associated with the school is invited and encouraged to participate in its manifold activities. Obviously, this calls for an openness in the communication and decision-making processes. This openness can, for example, be achieved through frequent staff and parent meetings as well as through the students' increasing involvement in the planning and execution of various class and school projects. In guiding the school's educational development, the administration endeavors "to ensure that staff at all levels, and students and parents, feel that the decision-making system is open and just, that they are treated with respect, and their concerns are given serious consideration" (Office of Social and Economic Development, letter dated 22 December 1990). The goal is to provide each student, parent, and staff member with opportunities for consultation before decisions that affect them are made. A number of issues are, in fact, decided not at the level of administration but rather through consensus reached in staff or class meetings. It is felt that such a "whole-school" approach increases motivation and commitment and establishes a strong foundation of unity with respect to the direction the development of the school should take.

\section{Students as Active Agents of Their Own Learning}

Before shouldering responsibility for others and the community, students must first be in a position to assume selfresponsibility. Commonly, there are few opportunities for this in a traditional, authoritarian school setting where the majority of decisions are made by the teacher or the administration and where the students are placed in a position of subordination and dependency. Normally, the teacher also retains full control over the learning, assigning students the role of receptacles to be filled with knowledge. One of the primary goals in implementing the principle of student participation would be to foster students' personal engagement in the educational process so that they could gradually "learn how to learn" and begin to take charge of their own learning. At the early stages, this would include acquisition of disciplined learning habits, development of goal setting competencies, and learning the use of tools such as dictionaries and other resource materials. The need for this acquisition of skills is made explicit in the above-discussed Bahá'í principle of independent investigation of reality, which assumes the willing acceptance of responsibility on the part of the students. 
Such learning does not occur in isolation. Interaction and cooperation with the teacher and peers are an essential part of the process. Not only should the students work with the teacher but even more so with one another and engage in peer tutoring (see 'Abdu'l-Bahá, quoted in "Bahá'í Education” 310). This cooperation and sharing develops a deeper understanding of what is being learned and enkindles a lasting interest in learning so that "later on, the children will of their own accord speak with each other concerning these same subjects ('Abdu'l-Bahá, quoted in "Bahá'í Education” 310; Bahá'í World 9: 543).

"Education as envisioned in the Bahá'í Writings makes the child collaborator in his own growth and in the development of his community (Bahá'í International Community, The Teacher's Situation 2). To achieve the latter objective, students need to be given opportunities to make decisions regarding their joint affairs and need to carry out cooperative activities. The Bahá'í writings praise those who work in groups ('Abdu'l-Bahá, Bahá'í World Faith 401) and state that "cooperative attitude and activity of human life" is not only "praiseworthy" ('Abdu'l-Bahá, Promulgation 338) but also "essential. . . . [to] happiness and development, individual and collective" ('Abdu'lBahá, Promulgation 35). Group work and cooperative activities would also provide the students with invaluable opportunities to practice the art of consultation and to develop their moral qualities in a meaningful social context.

\section{Teacher as an Example}

Ideally, "sharp distinctions between teacher and student disappear” (Bahá'í International Community, New Delivery Systems 1). For this to happen, "teachers must relinquish the idea that they are fountains of all knowledge. Rather, they should form a partnership with their students in a shared learning process, demonstrating by their example that they, too, are learners” (Bahá'í International Community, New Delivery Systems 2).

While working in such close collaboration with the students, the teachers still hold a key position as facilitators of the process. They act as guides, consultants, and sources and suppliers of information and materials. In this new role, they need "to practice patterns of behavior that create a climate of encouragement in the classroom" (Bahá'í International Community, New Delivery Systems 2) and to help develop a supportive relationship between themselves and the students as well as among the students. Teachers need to have confidence in the capacity of their students and expect each to be capable of a high standard of moral, social, and academic conduct. They need "a thorough understanding of the role self-concept plays in determining school success" (Bahá'í International Community, New Delivery Systems 2). They need to be able to make the students feel valued, respected, and appropriately challenged. They need to be sincerely concerned with the students' growth and development, in confidence discuss each student's strengths and weaknesses, and thus draw out the potential inherent in each, It is the teacher's function to enable and empower the student by gradually increasing the student's role in decision making and problem solving, thus enabling the student to gain an attitude of self-reliance. Such a supportive and collaborative approach "can have a liberating effect on students in that it helps them see themselves as directors of their own learning and as individuals who can determine the course their lives will take" (Bahá'í International Community, New Delivery Systems 2).

Teachers are held in high esteem. High also are the expectations placed upon them. First, they should have "a thorough knowledge of sciences and arts" and should be "distinguished for their high standards of conduct and general excellence ....” ('Abdu’l-Bahá, quoted in "Bahá'í Education” 273). They should set an example to the students and be "vanguards of the perfections of humankind ('Abdu'l-Bahá, Selections 129). Their guiding principle should be that "whatever a man's tongue speaketh, that let him prove by his deeds” ('Abdu'l-Bahá, Selections 139). Perhaps most important of all, teachers should approach their highly meritorious service with a pure motive and have a genuine concern for the best interests of their students (see Waite, A Charter for Bahá'í Schools 10).

Traditionally, "teaching. . . is for many one of the loneliest jobs in the world because teachers rarely work together” (Slavin, "Introduction to Cooperative Learning” 5). In a Bahá'í school, in the spirit of participation and cooperation teachers' involvement extends beyond their work in the classroom. Ideally, they plan in consultation the various aspects of their work, share ideas and materials and function as a team rather than individually. Great emphasis is also placed on the establishment of close teacher-parent collaboration, and parents are encouraged to take an active interest in their children's formal education and to become involved in the school's educational planning and development.

\section{Service to Community}

Another repeatedly emphasized aspect of participation is service to humanity. In this regard, the school's objective is to become firmly attached to the surrounding community and to find increasing opportunities to be of service initially through such fairly simple activities as environmental campaigns; visit to hospitals, orphanages, and homes for the aged; and through other project appropriate to the existing needs and the children's and teachers' abilities While these activities are intended to be of genuine benefit to the community they also have the added advantage of 
giving the students an orientation towards service and participation, exposing them to real-life challenges providing them with new experiences and skills, and enabling them to work side by side with adults outside the school community.

\section{The Central Role of Consultation}

Consultation plays a central role in any Bahá'í enterprise. It is the means by which individuals can participate in the decision-making process. In the worldwide Bahá'í experience, a systematic application of the principles of consultation empowers the group and all its members, and secures harmonious progress and development.

According to the Bahá'í teachings, the objective of those who engage i1 consultation is to determine the truth, to develop new and deeper understandings, to find the best possible solution to the problem at hand, and reach a genuine consensus. This is achieved through an open, frank, and hones sharing and evaluation of ideas. True consultation requires the full participation of all group members, whose obligation it is to express their views openly and to present their arguments with courtesy, dignity, care, and moderation. The goal is to conduct the process of consultation in such a manner that, while matters are fully and freely discussed, "the clash of differing opinions' ('Abdu'l-Bahá, Selections 87) —an essential condition for truth to emerge-is not allowed to give rise to feelings of conflict or contention. In true Bahá'í consultation, there is no ownership of ideas or persistence in one's views. It is not a debate or a confrontation, but a loving and constructive exchange of opinions. Therefore, those who take part in consultation are urged to approach their task with an unbiased and open mind, to detach themselves from their own opinions, to ensure that each member of the group has an equal opportunity to express his or her views and is allowed the freedom to do so. The participants are urged to respect and value the contribution of others, and never "belittle the thought of another ..." ('Abdu'l-Bahá, Selections 88). "Once a decision has been reached”-whether unanimously, by majority vote, or by those with authority to make the final decisions- "all members of the consultative body, having had the opportunity fully to state their views, agree wholeheartedly to support the outcome" (Universal House of Justice, Individual Rights 13). It is the Bahá'í view that "dissenting opinions are destructive to the success of the mission. When decisions are undertaken with total group support, wrong decisions can be more fully observed and corrected" (Rosenfeld and Winger-Bearskin, "Principles of Consultation” 37).

The Bahá'í approach to consultation has been compared to the method employed by scientists in their investigation of nature, as it follows "the normal steps of scientific enquiry: determining the exact nature of the problem, ascertaining the relevant facts, agreeing on the . . principles involved," and exploring the issues fully (Huddleston, "Just System" 37). At best, consultation is a creative process in which the final product, often a resolution or a plan of action, transcends any one individual's ideas. Thus, consultation has the capacity to release the potential of those engaged in the process and spur them to higher levels of achievement.

Consultation as a mechanism "for drawing out the constructive ideas of individuals and using them for the benefit of the entire system" (Universal House of Justice, Individual Rights 16) can be a powerful tool in the development and management of an educational institute, a fact that is becoming increasingly recognized in educational circles, as witnessed in the emergence of similar principles within systems known as schooldevelopment planning, management of change in education, action research, and cooperative learning. As "the cause of awareness and of awakening" (Bahá'u'lláh, quoted in Consultation 3), as a method of gaining "insight into things," and delving "into questions which are unknown" ('Abdu'l-Bahá, quoted in Consultation 8), as "the lamp of guidance" and "the bestower of understanding” (Bahá'u'lláh, Tablets 168), consultation also provides educators with a powerful methodology that enables the students to acquire knowledge, improve their analytical abilities, achieve new levels of understanding, use and develop their creative powers, gain social skills, and improve their moral character. Since consultation is an art that can and must be learned, its study and practice should be included in the curriculum so that teachers and students alike would become aware of the elements and attitudes involved and would, through effort and discipline, become skilled in the use of consultation (see Prentice, "Consultative Learning").

\section{Implications for the School's Instructional Approach}

Clearly, the Bahá'í writings offer invaluable insights on the aims and nature of education and provide the school with lofty—some might say "utopian"-goals. The challenge now is to translate these aspirations into reality and action.

The obvious implication of these insights is that the school will need to adopt—or, alternatively, to develop—an instructional approach that depart radically from the restrictive classroom environments typical of most school today (Solomon et al., "Creating" 1). It will need to be an approach that transforms teaching from an authoritarian teacher-centered system to a more egalitarian, learner-centered system that encourages and facilitates genuine interaction between students and teachers as well as among students. It will need to be an approach that, 
while promoting respect and obedience to authority, is not solely concerned with acquisition of knowledge but rather wit the maximum development of the students' manifold potentialities. It will need to be an approach that creates a positive and supportive learning environment and increases the students' self-esteem and self-reliance. It will need to be an approach that teaches the students to consult, to have concern for others, to participate, and to contribute to the common good. Finally, it will need to be an approach that enables the students to develop their moral character and attain qualities and skills that prepare them for dedicated service to humanity.

Much of current educational theory supports these aspirations. The approach most consonant with the school's aims and values appears to be cooperative education, widely implemented and researched at all age levels and in al subject areas, including bilingual and multicultural programs.

\section{An Overview of Cooperative Education}

The twin objectives of cooperative education are expressed in the oft-quote phrase "learning to cooperate, cooperating to learn." ${ }^{4}$ The former is concerned with the development of prosocial values, skills, and behaviors; the latter with the use of cooperation to enhance the learning process. These objectives are achieved by creating classroom conditions in which the use of cooperation an social skills becomes a necessity.

The promotion of cooperative education was vigorously renewed in the earl 1970s. This revival was rooted in the growing realization that traditional cooperative values, lost in the process of industrialization and urbanization were gaining increasing importance in today's society, with 70-80 per cent of jobs requiring a complex coordination of efforts (see Graves and Grave "Creating" 410). It is therefore argued that "understanding the nature of interdependent systems and how to operate effectively within them is au essential quality of future citizens. The question is not whether we will cooperate. The question is, how well will we do it?” (Johnson and Johnson, Learning Together and Alone 9).

\section{A Move away from Competition and Excessive Individualism}

Although not against competition as such, the proponents of cooperative education recognize the destructive nature of competition in most traditional classrooms and, based on extensive research, refute the central beliefs that have justified the continued reliance on competition, namely that (1) competition is part of human nature; (2) it motivates people to do better; (3) it is enjoyable; and (4) it builds character (Johnson and Johnson, Learning Together and Alone 13; see also Kohn, No Contest, ch. 2, for a detailed discussion of these points).

Often, "the mere presence of others" is sufficient to elicit competitive motives and besting behaviors (Allport quoted in Pepitone, "Children" 23). There are a great number of competitive features present in the traditional educational system. From their earliest days of schooling, students learn to compete for the teacher's attention, praise, and approval; they learn to be singly concerned with their own progress and success; they learn not to talk with one another nor to assist one another in their work; they enter into relentless rivalry with their classmates, knowing that only the best and highest achievements are acknowledged and appreciated, and their performance is compared, marked in relation to that of others, and graded on a curve. It is a situation in which one person's failure is perceived as a chance for others to succeed and make a favorable impression (see Slavin, "Introduction to Cooperative Learning” 5; Pepitone, “Children” 18ff).

The system, it has been discovered, has a particularly detrimental effect on low-achievers who, however great their personal effort and progress may be, always find themselves at the bottom of the class. Many either drop out or develop anti-social behaviors (Slavin, Cooperative Learning 2). Another negative effect is the development of peer norms that value mediocrity rather than high achievement, evidenced in the not uncommon labelling of academically successful students as "teacher's pets" and "nerds” (Slavin, Cooperative Learning 13-14, 50).

It is, however, acknowledged by most proponents of cooperation that competition, when suitably structured, can be a healthy means of motivating individuals to perform. Its use is recommended, for example, in such learning tasks as drill practice, and recall and review of well-learned materials-situations in which "the goal is not of large importance and the students can accept either winning or losing” (Johnson and Johnson, Learning 15). In such situations, the students generally have a more or less equal chance of winning. The objective, therefore, is not to eliminate competition totally but rather to reduce its inappropriate use and to teach students how to compete with enjoyment and to know when it is appropriate to do so (Johnson and Johnson, Learning x, 103ff.).

Similar observations apply to individualistic approaches to learning that refer to instructional strategies whereby "students work by themselves to accomplish learning goals unrelated to those of their classmates" (Johnson am Johnson, Learning 13). Decades of emphasis on individualism an individualistic learning structures have brought to light some of their less positive effects. It has been observed that when students work by themselves and for themselves, they often do so wholly without concern for others, possib1y even at the others' expense. They become isolated from peers and develop attitudes of self-centeredness and selfishness, with little commitment to the welfare 
of the group, or society itself (Johnson and Johnson, Learning 128-29 Kohn, No Contest 128-29; Pepitone, "Children" 48-54). Individualistic strategies largely ignore other than the cognitive dimensions of human development. There is increasing evidence to support the claim that even this goal may be compromised as personal relationships and social interaction "appear to form the matrix in which intellectual growth takes place" (Kelly Knowledge and Curriculum Planning 94). Condemning the inappropriate use of individualistic strategies that result in "narrowly conceived self-interest" and an "commensurate with competition" (Kohn, No Contest 129), does not, however, mean that less attention should be paid to the development of "genuine self sufficiency, conscience, autonomy, and non-conformity," in other words, to "the concern ... with the freedom to think and act on one's own, the commitment to deeply held values, the courage to risk disapproval and worse from others" (Kohn, No Contest 128). In fact, it has been shown that cooperative education furthers such goals, whereas competition and individualistic approaches fail in achieving them. Despite the heavy criticism of the outcomes of individualistic learning strategies, they too have their place in the classroom and can be used to great benefit in "unitary, nondivisible, simple tasks, such as the learning of specific facts or the acquisition of simple skills' (Johnson and Johnson, Learning 81-85).

\section{Learning to Cooperate}

In the early half of this century John Dewey argued that "if humans are to lean to live cooperatively, they must experience the living process of cooperation it schools" (Schmuck, "Learning to Cooperate" 2; cf. Lynch, Multicultural Education 110). Since then, cooperative education has grown into a strong movement, with an increasing emphasis on the development of attitudes of cooperation in students rather than simply using cooperation as a learning strategy. A survey of the latest literature reveals a growing agreement that especially at the pre-school and primary school levels, more time and attention needs to be dedicated to the social development of students, even at the expense of the academic curriculum. With the diminishing role that families and home play in the education of children, "schools must pick up the job of socializing the students in the values of caring and sharing" (Kagan, Cooperative Learning 2:4).

In a cooperative classroom, the studies claim, students learn to support, encourage, and help each other, listen carefully to each other's ideas, and settle disputes peacefully. They learn to give positive feedback to each other, are keen to promote each other's learning, and rejoice in each other's achievements. They learn to cooperate more effectively as they work in groups and to coordinate their studies and activities. They feel commitment to the common goals and develop a sense of responsibility for the welfare of the group, the class, the school, and the community at large. They also learn to take responsibility for their own behavior and for their academic work. In brief, they learn to handle interpersonal, intergroup, and intersocietal relations in constructive and creative ways and to assume their role as responsible members of society. Furthermore, they greatly enjoy doing so (Slavin, "Introduction to Cooperative Learning" and Cooperative Learning).

In a cooperative learning situation, these skills are typically taught parallel with the academic skills, by structuring learning tasks in such a way as to necessitate cooperation. The desired attitudes are further developed through an environment that is conducive to cooperation, e.g., classroom arrangement and management; cooperative games; explicit teaching of prosocial behaviors and skills; group discussions and exercises in group-decision making and interpersonal problem-solving; and home-based cooperative activities. Throughout the process, the emphasis is on the students' orientation toward each other rather than toward the teacher.

Some cooperative learning strategies acknowledge the students' successful social—and academic performance by giving extrinsic rewards, usually to the group rather than to its individual members. Examples of such rewards are academic bonus points; nonacademic incentives such as stickers, stars, extra free time, a party, an outing, etc.; and teacher recognition and praise (Johnson and Johnson, Learning 134-45.). It is, however, argued that heavy reliance on extrinsic rewards encourages competitive attitudes, as it leads to social comparison and thus to "intergroup versus outgroup biases," as well as undermines intrinsic motivation and "voluntarism." It is therefore far preferable to emphasize intrinsic rewards that are derived from the enjoyment of working together, making progress, achieving goals, etc. (Battistich et al., "The Child Development Project” 15-17).

\section{Cooperating to Learn}

In the above discussion, the term "cooperative education" has been used to cover a wide range of cooperative concepts, with particular emphasis on the concern for the social development of students. The term "cooperative learning" is often used in a more restricted sense, referring to the distinctive instructional methods and techniques that form an integral part of the movement.

Over the last two decades, a dozen or so structured and systematic cooperative-learning strategies have been developed and thoroughly tested and researched. Even a brief description of these methods—-the best known of 
which are STAD, TGT, Jigsaw I and Jigsaw II, Group-Investigation, and Co-o Co-op-is beyond the scope of this discussion. Detailed accounts can, however be found in a multitude of published materials, e.g., Kagan, "Dimensions 69-96, and Slavin, Cooperative Learning, both of which works present a analysis of each of the above methods.

It has been pointed out that the variations between the existing cooperative learning structures reflect the distinct educational beliefs held by their advocates (Kagan, "Dimensions" 75). Thus, the structures range from those close to the rigid, traditional, teacher-centered learning situations to those that emphasize learning experiences tailored to the interests and abilities of the individual student. They vary from product-oriented to process-oriented, from teacher-directed to student-directed, from the perception of student as an object to be manipulated into learning to the perception of student as the subject of his or her own learning, from emphasis on the student's academic achievement to an emphasis on prosocial development (see Kagan, "Dimensions" 75). STAD, TGT, and Jigsaw I and II fall at the more traditional end of the spectrum, with primary emphasis on the acquisition of predetermined knowledge and basic skills; whereas “Co-op Co-op and Group-Investigation embody a more democratic philosophy of education than the other techniques because they give greater control to students over what is to be learned and how it is to be learned (Kagan, "Dimensions" 81).

The basic concept is, crudely stated, that the more teacher talk there is in classroom, the less learning takes place, whereas personal experiences an interaction among students increase learning. There is, of course, nothing new in the concept of group work as such. A cooperative-learning group, however, differs from a traditionallearning group in significant ways:

- Preferably, the group is composed of mixed abilities and mixed backgrounds (with regard to interests and hobbies, nationality, culture race, and sex);

- The group strives toward a common goal that can be successfully achieved only if each group member takes personal responsibility for the learning outcome and actively contributes to the group effort;

- The members are accountable not only for their own but also for other group members' achievement;

- Group leadership, as well as various roles and responsibilities are shared among the members;

- The teacher, while intervening minimally, observes the learning process and the social interaction, and gives the group feedback on both;

- Finally, the group analyzes and reflects on the learning experience to asses its performance and summarize educational outcomes.

Whereas in the past, a teacher interested in cooperative strategies would usually choose one or at most two of the many cooperative-learning structures for classroom use, the trend now is to combine several methods. It has been observed that through the combination of a range of structures in designing a lesson more powerful results are obtained. In this multistructural approach, the cooperative- learning structure best suited for the particular task is selected, and thus a lesson flows from structure to structure (see Kagan in foreword to Andrini, Cooperative Learning, and foreword to Stone, Cooperative Learning and Language Arts).

\section{Positive Effects of Cooperative Learning}

There is an abundance of empirical evidence that supports the efficacy of cooperative-learning strategies over traditional classroom methods. The well-documented findings of some 100 research projects show beyond doubt that cooperation is effective in increasing student achievement and is beneficial for the development of positive intergroup relations and prosocial behaviors and attitudes (Slavin, “Introduction to Cooperative Learning” 18). The impressive list of positive outcomes includes:

- Improved academic learning at all ability and school levels, in all subject areas, and in urban, suburban, and rural schools;

- Increased critical-thinking competencies and higher-level reasoning abilities, enhanced through interaction with peers;

- Greater self-esteem and self-acceptance, resulting from better peer relations and improved academic achievement;

- Higher motivation and self-direction and therefore more on-task behavior and pro-academic attitudes, which are further enhanced as the student is enabled to experience success in the given task;

- Better intergroup relations and increased cross-ethnic interaction and friendships;

- More oral participation, which enables the students to express themselves with greater confidence and fluency, as well as to listen with respect to the opinions of others;

- Improved social skills and ability to view situations from others' perspectives;

- Better psychological health, with reduced anxiety and depression. 
(For details, see Feldman, Learning to Cooperate...Cooperating to Learn 4.3; Johnson et al., Circles of Learning 23-28; Johnson and Johnson, Learning 39-49; Kagan, Cooperative Learning 3.1-3.3; Lynch, Multicultural Education 115; Slavin, "Introduction to Cooperative Learning" 10-11; Slavin, Cooperative Learning 13-53.)

By employing consultation as the primary method of instruction, cooperative-learning strategies develop understanding, trust, and unity among all participants. Most evaluations of cooperative learning also indicate that students who work together like school more than those who do not, that they generally enjoy learning, and that they experience the work as social and exciting (Slavin, "Introduction to Cooperative Learning” 9, 13).

There is further evidence that cooperative learning "holds tremendous potential for language development" and enhances "second-language learning linguistically heterogeneous bilingual classroom situations" (McGroarty, "The Benefits," and Snow, "Instructional Methodology" 166-67). This finding has particular relevance for the School of the Nations, whose students originate fro nearly forty countries, with a variety of language and cultural backgrounds.

\section{Working Together Towards New Understandings and Practices}

The positive outcomes of cooperative education-the preceding list of such benefits is by no means comprehensive-are of utmost significance for the planning of any educational program. The two research projects that seem have the most to offer to the School of the Nations' efforts "to formulate adequate teaching curriculum which would be in full harmony with the spirit the Bahá'í Teachings" (Shoghi Effendi, quoted in "Bahá'í Education" 302) the "Child Development Project" by Watson et al. and an "Ecologic Approach" researched by Graves and Graves (summarized respectively in Appendices 1 and 2 of this article). These studies examine cooperative education from a holistic point of view, promoting, as stated in a description of the Child Development Project, and apparently equally applicable to the mode proposed by Graves and Graves, "a comprehensive set of home and school activities and practices that would incorporate . . . : warm and supportive adult-child relations; highlighting and explaining the importance of prosocial values; practice at collaborating with others and acting prosocially; discussion of and reflection on the reasons for moral actions; and understanding discussing, and reflecting on the feelings, motives, and needs of others (Watson et al., "The Child Development Project" 60). Such a holistic approach fully integrated into the academic curriculum, is gaining support from a increasing number of researchers who maintain that the use of cooperative learning strategies in selected subject areas only and with no whole-school effort to create a climate conducive to cooperation will have minimal impact on the prosocial development of students, who will, if simultaneously exposed to cooperative and competitive strategies, receive mixed messages about the desired behaviors (Curran, Cooperative Learning, foreword; Graves an Graves, “Creating” 410; Solomon et al., "Cooperative Learning” 236).

Comparison of the ideals and objectives of the two abovementioned project with those inspiring the educational planning of the school reveals a number of similarities. These include:

- Provision of a loving, caring, and supportive environment with harmonious social relationships that nurtures the students' growth and development an facilitates the fullest realization of their potential;

- Emphasis on the students' personal, moral, and social development actualized in their conduct while pursuing academic goals;

- Focus on the development of a positive self-image and high self-esteem, coupled with respect for the unique qualities and talents of others and appreciation of individual differences;

- Development of self-discipline based on internalized moral values rather than reliance on authoritarian, power-assertive control techniques, and a problem-solving rather than a punitive approach to classroom management;

- Maximization of intrinsic motivation through acquisition of self-knowledge, self-esteem, and selfdetermination as well as through suitably challenging and inherently interesting learning tasks;

- Development of the students' ability to assume responsibility for self and others;

- Use of an investigative, consultative, and collaborative instructional methodology;

- Close cooperation between administration and teaching staff, including active participation by each in the planning and implementation of the curriculum and a schoolwide approach to cooperation and to discipline;

- Redefinition of the role of teachers who perceive themselves as partners with the students in a collaborative learning process rather than as the sole decision makers and transmitters of knowledge;

- Emphasis on the involvement of parents in their children's education and their participation in a wide variety of school activities;

- Commitment to service and organization of activities that are of genuine benefit to the community at large. 
Such similarity of ideals and objectives, coupled with the fact that the "Child Development Project" and the "Ecological Approach" have been rigorously researched over a number of years by experienced professionals, strongly suggests that the two projects could greatly enrich the school's planning and development process by offering a sound, workable model, with practical guidelines on how to achieve the stated goals. The school's administration therefore agreed to carry out a few experimental activities to gauge the teachers' and students' responses and to assess how to plan for a more systematic implementation of cooperative strategies.

\section{Early Experiments}

As the first step, the entire teaching staff participated in in-service training that consisted of a series of seminars and workshops, followed by formal and informal consultative meetings. The purpose of these sessions was to familiarize the teachers with the concept of cooperative education and jointly to plan and implement activities demonstrating cooperative-learning strategies. To an increasing extent, the seminars and workshops-whose content was largely based on ideas and practices promoted by the two abovementioned projects-were designed to utilize cooperative principles and methods, thus providing the participants with first-hand experience of the benefits and challenges cooperative-learning situations.

Drawing on the ideas proposed by Graves and Graves ("Creating" 413ff.) the teachers began with some "ground-laying" activities at the whole-school and whole-class levels. These included non-academic games and other simple cooperative tasks. The fact that the project commenced in September, soon after the start of the new school term, offered an excellent opportunity to practice so-called team-building, class-building, and school-building activities aimed helping the students and teachers get acquainted with each other, develop class and school identity, and establish mutual support structures (e.g., buddy systems) across class boundaries. Practicing the principles of universal participation, cooperation, and consultation, Form 1 students, for example organized an international luncheon; Grades 5 and 6, a pancake party; and Grades 1, 2, and 3, a joint field trip to an island park. These activities were greatly enjoyed by teachers and students alike. In addition to the aspects of fellowship and fun, the activities were also designed to achieve three learning objectives, as each activity included an academic content, a language-learning content, and a cooperative-social skills content. It was observed by some of the teachers that the amount of authentic language learning that occurred during these highly motivating activities was clearly above the norm.

At the beginning of the term, a number of classes were also involved in negotiating principles of classroom management. This process include discussions about behavioral norms, such as acceptable language, care for property, cleanliness and order; and the setting up of control systems that would involve the students themselves. In these situations, the children's limited English-language capabilities presented considerable difficulties, especially in the lower grades. Nevertheless, some classes developed "class rules" poster which were then displayed on the wall and which are periodically revised.

In the kindergarten, a different kind of experiment took place, occasioned by the general dissatisfaction with the existing system of assigning the children into more or less homogeneous learning groups. When the children were, in accordance with cooperative-learning principles, reorganized into heterogeneous groups, the teachers reported most encouraging changes in the children's learning and behavior as well as in their own perception of the groups. It was particularly noted that the teachers' negative expectations with regard to the lowachieving groups disappeared once the groups were organized on a more equal basis. Similar observations have been made in the lower primary classes.

All in all, the majority of the teachers were greatly enthused with the concept of cooperation and found the experiments successful and rewarding. In principle, the teachers were therefore in favor of cooperation. In practice, however, it was soon discovered that a number of obstacles would need to be overcome before the new approach could be extensively implemented.

\section{Current and Future Concerns}

The most crucial element in the implementation of any new educational approach appears to be time- time to develop new understandings, time to plan and work together, time to design an appropriate curriculum, and, finally, time to evaluate achievements. In the midst of numerous pressing issues, such as the challenges of the school's bilingual program and the urgency to devise supplementary lesson plans and materials, the administration and teachers soon realized that, despite their general enthusiasm for the cooperative approach, it would be necessary to narrow the scope of the project and to undertake its implementation one step at a time.

Three priorities gradually emerged. First, it was felt that in order to achieve other objectives, it would be essential to focus on the establishment of a distinctive Bahá'í atmosphere, with emphasis on the development of loving and caring attitudes in staff and students, encouragement of universal participation, and an increased use of 
consultation. Much of the early discussions centered on defining a set of commonly held values and the adoption of systematic, consistent, schoolwide practices with regard to acceptable standards of behavior. Efforts to encourage the development of a shared understanding of fundamental Bahá'í and educational principles have immersed the teachers and administration, who represent a variety of national, cultural, religious, and professional backgrounds, in a number of joint consultations. It is becoming apparent that through their active participation, teachers are developing a sense of ownership for the project, a fact that breeds enthusiasm for the overall development of the school and minimizes the feelings of anxiety and uncertainty so common in the face of unfamiliar and untried systems. These efforts have also brought about closer relations between administration and teachers, and among teachers, and increased their mutual trust and supportiveness, thus meeting one of the first conditions for the development of a participatory and cooperative school climate. Students and parents have also been involved in the consultative process, although to a more limited extent, and on-going efforts are being made to increase their participation.

The second priority identified was to intensify and systematize the development of a curriculum that would “reflect Bahá'í ideals and operate within the framework of Bahá'í principles of education” (Bahá'í International Task Force on Education, "Outline for Workshops" 1), at the same time taking into account the particular needs of the local culture arid continuity. To this end, the school has set up a curriculum-development team, comprising individuals who have expressed willingness to dedicate their time and energies to this project. Currently, the team is working on three curricular elements, the first dealing with moral education, the second with the development of consultative skills, and the third with the concept of the oneness of humankind. Throughout the task, consideration is being given to the variety of ways in which the adoption of cooperative strategies would shape the curriculum.

Finally, to continue the process begun in September, 1991, a few of the teachers are taking steps to integrate cooperative concepts into their classroom practice. They are developing cooperative lesson plans, experimenting with different strategies and group compositions, and observing the results, reflecting on those results, and making whatever modifications seem necessary. The goal now is to introduce, at a gradual pace, such cooperative-learning structures that are consonant with the values and goals of the school and to examine the impact on a more systematic basis, applying the principles of action research (Lomax, "Action Research Approach" 7ff.; see also Bahá'í International Task Force on Education, “Outline” 1). It has already become apparent that the process is best begun with younger children who have had less exposure competitive attitudes and are therefore more naturally inclined to learn cooperation - at their level of maturity. In the lower grades, there is also great latitude with regard to content and methods, a factor that allows the teacher more freedom to experiment. As experience is gained in the implementation of various aspects of the model, it is hoped-depending, of course, on the observed results - to increase the use of cooperative learning to the recommended 60 percent of class time (Edwards and Stout, “Cooperative Learning” 39).

As already indicated, transition from a traditional competitive approach to new participatory and cooperative approach requires a great deal of time an energy. First, it is not possible for the staff to change their attitudes and replace long-established practices before the importance and relevance of the new ones fully understood. Also, even those committed to the new concepts feel obligated keep up with the tight academic schedule imposed by the outside curricula school has temporarily adopted, with the result that little time is left for either students or teachers to learn the new skills required for the effective implementation of participation and cooperation. Second, traditional examination procedures control and direct the curriculum and the teachers by emphasizing purely cognitive learning outcomes (see Kelly, Knowledge and Curriculum Planning 218). Finally, parental attitudes and expectations mostly favor traditional approaches and thus constrain the school's efforts to move in new directions.

Soon, it would seem, the school will have to determine to what extent it can commit itself to a participatory - cooperative approach to learning. As has already been seen, the full implementation of the approach would require far-reaching changes that would have a profound effect on the administration, the teacher and students' roles and relationships, task structures, reward systems, classroom management and authority systems, and, as emphasized above, methods assessment and evaluation. Failure to change any one of the above areas might seriously impede the achievement of the cooperative goals. However, based the timeframe of the projects studied so far, implementation of the require changes would take from five to ten years of well-planned effort.

Although many issues have already been solved, the school still needs to answer a multitude of questions before making such long-term commitment. For example, how likely is it that the same positive outcomes would be achieved in the School of the Nations' bilingual, multicultural environment as have been achieved in the two projects cited above? To what extent do the conditions and findings of these two projects apply to the School's educational setting and its largely Chinese student body? What modifications would need to be made to the existing frameworks? What kind of materials would need to be developed? What impact would the students' limited 
language ability have on the implementation of the program? To what extent would the parents and the community accept the approach and be willing and able to get involved in their children's educational process? And finally, what human and financial resources would be required, and would the School be able to raise the resources?

The most fundamental question would appear to be whether the participatory and cooperative principles could be beneficially applied when the majority of students and a considerable number of teachers come from a cultural environment that requires intense competition, and when their views and expectations about education are likely to be diametrically opposed to those promoted by cooperative methods (see Bond, Beyond the Chinese Face 28-31). Their other attitudes might, however, strongly support cooperative learning goals; for, the Chinese have high regard for moral conduct, accept social restraints, and socialize their children "for lifelong interdependence with others by developing skills and values which promote harmony” (Bond, Beyond the Chinese Face 118).

\section{Summary and Conclusion}

This article has attempted to explore some major Bahá'í perspectives on education and to identify their implications for the School of the Nations' curriculum planning. First, the discussion focused on the fundamental nature of moral education, with its emphasis on an attitude of service to humanity and the development of global awareness. In the Bahá'í view, the goal of education, it was seen, is the full realization of human potential. Recognition of the exalted nature of human beings and their role in society provides motivation for the highest possible achievement in moral, social, academic, and aesthetic development. This achievement can best take place in a climate that encourages independent investigation of reality. The student's growth is fostered in an affectionate and supportive environment in which order and discipline are maintained through gentle, noncoercive measures. Everyone within the school community, from the young child in the kindergarten to the highest-ranking administrator, is involved in developing this new model of education, in a spirit of participation and consultation not only in the management of the school's affairs but also in its instructional context. In this entire process, one of the key issues is the quality of the relationship between the teacher and student, the former facilitating learning through instruction and example and the latter growing increasingly self-determinate and self-directed.

Developing such a model and method is a major undertaking. In this task, assistance is sought from current educational theories and practices, most promising of which, for the School's purposes, appear to be the various cooperative approaches. Despite a number of fundamental conceptual differences, the School of the Nations and some, if not all, of the cooperative programs are moving in a parallel though not identical direction. Therefore, School is eagerly exploring these programs and experimenting with their strategies, though with a degree of caution.

Obviously, this discussion is not complete. It does, however, chart a possible course for the School of the Nation's development planning. While eager to see Bahá'í principles fully integrated into the educational program, the administrators and teachers are well aware of the enormity of their task.

Endeavor, ceaseless endeavor is required. Nothing short of an indomitable determination can possibly achieve it. ('Abdu'l-Bahá, Secret 66)

\section{APPENDIX 1 The Child Development Project (CDP)}

The Child Develop Project was begun in 1982 and has involved three suburban elementary schools in northern California. It was based on the recognition of the fact that children's social development is often neglected during those years that are "believed to be crucial in the establishment of social attitudes, beliefs, and behaviors," and was envisioned "to have a substantial impact on children's social development" (Solomon et al., "Program" 399). The researchers describe it as "a comprehensive longitudinal intervention program designed to enhance the social and moral development of children through systematic changes in the classroom, school, and home environments" (Battistich et al., "The Child Development Project" abstract). They further explain that it "consists of five theoretically consistent and reinforcing classroom components, which are supported by consistent school-wide and home activities. The components are: Cooperative Learning, Developmental Discipline, Helping Activities, Highlighting Prosocial Values, and Promoting Social Understanding.”

The model takes into account four domains: (1) it lists types of prosocial behavior (such as sharing, helping, compromising, being considerate); (2) it presents a broad range of internal characteristics that are assumed to mediate the performance of prosocial behavior such as cognitive factors (e.g., knowledge and understanding of 
prosocial behaviors), affective/motivational factors (e.g., commitment to prosocial values), behavioral competencies (e.g., skills for effective social interaction) and personality factors (e.g., self-control, self-esteem); (3) it identifies the likely external and environmental conditions that influence the behavioral outcome (such as opportunities to learn prosocial behaviors, participation in prosocial activities, approval or reward for prosocial behavior); and (4) it explains the potential psychological mechanisms by which the environmental determinants might achieve their effect (Solomon et al., "Program” 372).

The program consists of

(1) cooperative activities, in which students work on learning tasks in cooperative groups and play cooperative games, and in which family members work or play together cooperatively; (2) regular participation in helping and sharing activities; (3) opportunities for children to experience others (adults as well as children) setting positive examples (i.e., being considerate, cooperating, taking responsibility, helping, and sharing); (4) role playing and other activities designed to enhance children's understanding of other people's needs, intentions, and perspectives; and (5) positive discipline, which includes the development and the clear communication of rules and norms that emphasize the individual's rights and responsibilities with respect to others, as well as discipline techniques that use the minimal force necessary to obtain compliance, and that explain the reasons for rules; emphasize the potential effects of one's behavior on others; provide firm, fair, and consistent guidance; foster nurturant adult — child relationships; and offer age-appropriate decision-making opportunities for children. (Solomon et al., "Program” 376)

It is assumed that

Cooperative activities incorporate several of the environmental determinant assumed in our model to be important in the development of prosocial characteristics Thus, children in cooperative groups have many opportunities to learn prosocial behaviors and to participate in prosocial activities because, in order to achieve group goal, it is often necessary to negotiate with, help, and encourage other group members. In addition, approval and disapproval (or reward, punishment, and nonreward) for prosocial and antisocial behavior will come about naturally in cooperative group as the members work toward the group goal. Group members who help the group to reach its goals and to function in a smooth and pleasant manner (probably always an implicit goal) will usually receive the most approval from the other group members as well as from any adults who may be present. The expression of approval and disapproval is probably also an important way in which group norms values, and expectations are communicated; for example, it is expected that adult and children involved in cooperative activities will show approval for behaviors that reflect such prosocial norms as fairness, consideration for others' views and opinions and responsibility to the group. Finally, cooperative groups provide many opportunities for reciprocal peer interaction, especially groups that are composed of equal-status members, involve much collaborative activity, and are maximally directed by the members themselves. (Solomon et al., 'Program” 380)

In their recent evaluation of the success of the project, the designers stab that "we generally are quite encouraged by our efforts." They feel that the basic approach to sociomoral training is effective. However, the implementation o the "complex and comprehensive program," now in its ninth year, has required more time and effort, especially in the training of teachers, than was initially expected. The effects of the program on children's social attitudes, skills, ant behavior have been found to be "strong and consistent" (Battistich et al., The Child Development Project 37-41).

\section{APPENDIX 2 An Ecological Approach}

Based on their experience and research as anthropologists, Graves and Graves are of the opinion that "learning in general, but particularly cooperative small-group learning . . . emerges out of the total social and physical environment within which the person is immersed” (“Creating” 403). Their comparison of children reared 
in traditional village and island communities with those reared in modern urban environments showed clearly that the former were far more sociocentric, altruistic, cooperative, and socially responsible than the latter, who were found to be more egocentric, individualistic, rivalrous, and competitive ("Creating” 404). Their California-based demonstration project, "Culture and Cooperation-Classroom Applications," which they describe as a "systems model of learning in which cooperative behavior is an inextricable part of a total social context and arises spontaneously from interaction within the group" (Graves and Graves, "Creating” 405), grew out of these observations.

To begin with, the researchers contrasted "the contextual features of traditional cooperative village settings with those of a conventional Western classroom." They found "clear differences in the organization of physical space, in patterns of social interaction, and in types of tasks, goals, and rewards th2a these two settings provide." Based on this observation, they developed their "ecological approach” (Graves and Graves, "Creating” 405).

Graves and Graves maintain that creation of an environment supportive of cooperative learning requires a complete shift of perspective and attitudes by parents, teachers, and entire school staff. They suggest that school personnel examine their programs for consistency with five general guidelines which characterize their model (“Creating” 410). These arc: (1) creating a holistic rather than a piecemeal approach, one that incorporates individualistic and competitive activities within a cooperative framework; (2) placing cooperative classroom activities within the larger system of which the class is a part; (3) enlisting a wide network of participants to contribute actively to students' prosocial development; (4) making more explicit the interpersonal processes among students; and (5) being patient, realizing that, with a sequence of well-structured learning experiences, change will proceed in stages (“Creating” 410-13).

The goal of the project is to create a school and classroom environment that is maximally conducive to cooperation. Graves and Graves have established ten principles of cooperative learning that facilitate the process of restructuring the classroom, a process they call "ground laying" and "preparing the soil."

This process involves the entire class and pays particular attention to the integration of individuals into a meaningful whole ("Creating" 414), Contrary to what frequently occurs in a cooperative classroom, the writers propose that only after the class has become a cohesive entity should it be divided into long-term learning teams. In the early stages, they say, it is preferable that students shift between groups of varying sizes and compositions throughout the day until the get to know all of the class members and feel comfortable working wit practically anyone (“Creating” 415).

The ten principles, briefly summarized, are:

- Development of school and classroom identity (i.e., whole-group entity cohesion, and bonding);

- Establishment of unity in diversity (i.e., appreciation of individual differences and the diversity of talents and characteristics in the student body);

- Involving the students, teachers, staff, and parents in the establishment of group norms and control procedures (i.e., sharing and delegating authority);

- Sharing responsibility and the work-load at all levels (i.e., assigning role and functions to each and every one);

- Working together for common goals (i.e., group goals);

- Ensuring intrinsic rewards (i.e., rewards that are inherent in the activity itself, in other words, that arise for a large part out of the pleasure of working together);

- Exchanging talents, skills, and services (i.e., learning how each can contribute to the common goal or be of service to someone else);

- Adoption of practical and relevant rather than purely academic tasks;

- Creating an interactive physical environment (i.e., classroom arrangement conducive to cooperation, sharing of materials and equipment, etc.);

- Developing cooperative interaction between students (i.e., practicing interpersonal skills, using competition within the framework of cooperation).

Each of the ten principles affects a variety of outcomes conducive to cooperative behavior; it is the interaction of these ten principles within the total system that promotes cooperation ("Creating" 413-29).

Finally, Graves and Graves (“Creating” 429-33) recommend an order in which cooperative methods should be gradually introduced into a school:

- Laying the groundwork through teaching and practicing cooperative skills and attitudes at a whole-class level;

- Teambuilding, i.e., teaching and practicing the above at the small-group level;

- Using simple teamwork (e.g., cooperative methods such as TGT and STAD);

- Coordinated teamwork (through methods such as Jigsaw I and Jigsaw II); 
- Group research and investigation (Co-op Co-op and Group Investigation methods);

- Group creativity (e.g., an advanced type of brainstorming known as synectics).

\section{Notes}

1. The school was established in 1988 by individual Bahá'ís and is now under the aegis of the Badi Foundation (incorporated in 1990). Currently, it has a total of 280 students and 23 teachers, representing 40 nationalities.

2. The following quotations from the writings of 'Abdu'l-Bahá clarify this issue further: “Training in morals and good conduct is far more important than book learning. If, however, the child be trained to be both learned and good, the result is ugh upon light" (Selections 135-36). "Good behaviour and high moral character must corn first, for unless the character be trained, acquiring knowledge will only prove injurious. Knowledge is praiseworthy when it is coupled with ethical conduct and virtuous character; otherwise it is a deadly poison, a frightful danger" (quoted in "Bahá'í Education" 278). "Abdu'l-Bahá explains that "if a person be unlettered," yet possesses "the spiritual characteristics and praiseworthy virtues of humankind" and is "clothed with divine excellence," that person "will contribute to the welfare of society, and his inability to read and write will do him no harm" (quoted in "Bahá’í Education" 282).

3. "Regard man as a mine rich in gems of inestimable value. Education can, alone, cause it to reveal its treasures, and enable mankind to benefit therefrom” (Bahá'u'lláh, Gleanings 260).

4. As in the title of the collection of papers originally presented at the Second Conference of the International Association of Cooperation in Education, held at Brigham Young University, Provo, Utah, July, 1982; see Slavin et al., "Learning to Cooperate"

\section{Works Cited}

‘Abdu’l-Bahá. Foundations of World Unity. 4th ed. Wilmette, IL: Bahá'í Publishing Trust, 1979.

—. Paris Talks: Addresses given by 'Abdu’l-Bahá in Paris in 1911, 11th ed. London: Bahá'í Publishing Trust, 1969.

. The Promulgation of Universal Peace. Talks Delivered by 'Abdu'l-Bahá during His Visit to the United States and Canada in 1912. Comp. Howard MacNutt. 2d ed. Wilmette, IL: Bahá'í Publishing Trust, 1982. Selections from the Writings of 'Abdu'l-Bahá. Comp. Research Dept. Bahá'í World Centre. Trans. Marzieh Gail et al. Haifa: Bahá'í World Centre, 1978.

—. Some Answered Questions. Comp. and trans. Laura Clifford Barney. 4th ed. Wilmette, IL: Bahá'í Publishing Trust, 1981.

—. The Secret of Divine Civilization. Trans. Marzieh Gail. 2d ed. Wilmette, IL: Bahá’í Publishing Trust, 1970.

Andrini, B. Cooperative Learning: A Multi-Structural Approach. San Juan Capistrano, CA: Resources for Teachers, 1991.

“Bahá'í Education.” Comp. Research Dept. Bahá'í World Centre, August 1976. In Compilation of Compilations. Prepared by the Universal House of Justice 1963-1990. Maryborough, Victoria: Bahá'í Publications Australia, 1991, Vol. 1: 245-314.

Bahá'í International Community, United Nations Office. A Survey of Basic Education Activities in Selected Bahá'í Communities, 1988.

—. New Delivery Systems for Basic Education. Statement submitted to "World Conference on Education for All: Meeting Basic Learning Needs," 5-9 March 1990.

- The Teacher's Situation: The Determining Factor of Quality Education for All. Statement submitted to "World Conference on Education for All: Meeting Basic Learning Needs," 5-9 March 1990. 
Bahá'í International Task Force on Education. "Learning in a Whole World: A Bahá'í Approach to Education.” Bahá'í Canada (Jan-Feb. 1990): 4-7.

"Outline for Workshops on Bahá'í-Inspired Curricula.” Unpublished manuscript.

Bahá’í World, The. Vol.9. 1940-1944. Wilmette, IL: Bahá’í Publishing Trust, 1945.

Bahá'u'lláh. Epistle to the Son of the Wolf. Trans. Shoghi Effendi. 3d ed. Wilmette, IL: Bahá'í Publishing Trust, 1988.

— Gleanings from the Writings of Bahá'u’lláh. Trans. Shoghi Effendi. 2d ed. Wihnette, IL: Bahá’I Publishing Trust, 1976.

. The Hidden Words of Bahá'u’lláh. Trans. Shoghi Effendi. Wilmette, IL: Bahá'í Publishing Trust, 1939.

—. Kitáb-i-Íqán [The Book of Certitude]. Trans. Shoghi Effendi. 2d ed. Wilmette, IL: Bahá'í Publishing Trust, 1950.

. Tablets of Bahá'u'lláh Revealed after the Kitáb-i-Aqdas. Comp. Research Dept. Bahá'í World Centre.

Trans. H. Taherzadeh et al. 2d ed. Wilmette, IL: Bahá’í Publishing Trust, 1978.

Bahá’u’lláh and ‘Abdu’l-Bahá. Bahá'í World Faith. Rev. ed. Wilmette, IL: Bahá'í Publishing Trust, 1956.

Battistich, V., et al. "The Child Development Project: A Comprehensive Program for the Development of Prosocial Character.” In W. M. Kurtines and J. L. Gewirtz, eds. Handbook of Moral Behavior and Development. Vol. 3. Application. Hilisdale, NJ Erlbaum, forthcoming.

Blumenthal, E. “Coping with Conflict.” In Hooshang Nikjoo, ed. Trends in Bahá’í Education: 101-9.

Bond, M. H. Beyond the Chinese Face: Insights from Psychology. Hong Kong: Oxford University Press, 1991.

Consultation: A Compilation. Comp. Research Dept. Bahá'í World Centre. Wilmette, IL Bahá’í Publishing Trust, 1980.

Curran, L. Cooperative Learning Lessons for Little Ones: Literature-Based Language Arts and Social Skills. San Juan Capistrano, CA: Resources for Teachers, 1991.

Edwards, C., and J. Stout. “Cooperative Learning: The First Year.” Educational Leadership 47.4 (Dec. 1989-Jan. 1990): 38-41.

Esslemont, J. E. Bahá'u’lláh and the New Era. 5th ed. Wilmette, IL: Bahá'í Publishing Trust, 1980.

Feldman, K. Learning to Cooperate. .. Cooperating to Learn: A Three-Part Team Workshop Series. Sponsored by Sonoma County SELPA, 1989.

Graves, N. B., and T. D. Graves. “Creating a Cooperative Learning Environment: Ecological Approach.” In R. Slavin et al., eds. Learning to Cooperate, Cooperating t Learn: 403-3 6.

Hatcher, W.S., and J. D. Martin. The Bahá'í Faith: The Emerging Global Religion. S Francisco: Harper \& Row, 1985.

Huddleston, J. “A Just System of Government: The Third Dimension to World Peace.” In The Bahá'í Faith and Marxism: Proceedings of a Conference Held January 1986. Ottawa: Bahá'í Studies Publications, 1987: 35-41.

International Teaching Centre, Bahá'í World Centre. Letter to the Continental Boards of Counselors, 2 November 1989.

Johnson, D. W., and R. T. Johnson. Learning Together and Alone: Cooperative, Competitive, and Individualistic Learning. Englewood Cliffs, NJ: Prentice Hail, 1991. 
Johnson, D. W., R. T. Johnson, and E. Johnson Holubec. Circles of Learning: Cooperation in the Classroom. Edina, MI: Interaction Book Company, 1986.

Jordan, D. C. Becoming Your True Self. Wilmette, IL: Bahá’í Publishing Trust, 1968.

Kagan, S. Cooperative Learning. San Juan Capistrano, CA: Resources for Teachers, 1990. "Dimensions of Cooperative Classroom Structures.” In R. Slavin et al., eds. Learning to Cooperate, Cooperating to Learn: 67-96.

Kelly, A. V. Knowledge and Curriculum Planning. London: Harper and Row, 1986.

Kohn, A. No Contest: The Case against Competition. Boston: Houghton Mifflin, 1986.

Kurtines, W. M., and J. L. Gewirtz, eds. Handbook of Moral Behavior and Development. Vol. 3. Applications. Hillsdale, NJ: Erlbaum, forthcoming.

Lights of Guidance. Comp. Helen Hornby. 2d ed. New Delhi: Bahá'í Publishin Trust, 1988.

"Living the Life," in Compilation of Compilations. Maryborough, Victoria: Bahá'í Publications Australia, 1991, Vol. 2: 1-27.

Lomax, P. “An Action Research Approach to Developing Staff in Schools.” In P Lomax, ed. Managing Staff Development in Schools: An Action Research Approach. Bera Dialogues No. 3. Clevedon: Multilingual Matters, 1990: 7-19.

Lynch, J. Multicultural Education in a Global Society. London: The Falmer Press, 1989.

McGroarty, M. "The Benefits of Cooperative Learning Arrangements to Second Language Instruction.” NABE Journal 13 (Winter 1989): 127-43.

Nikjoo, Hooshang, ed. Trends in Bahá'í Education: Proceedings of the Second Symposium on Bahá'í Education 1989. London: Bahá’í Publishing Trust, 1990.

Nucci, L. P., ed. Moral Development and Character Education: A Dialogue. Berkeley, CA: McCutchan, 1989.

Office of Social and Economic Development, Bahá’í World Centre. Letter to the Badí Foundation, 22 December 1990.

Pepitone, E. A. "Children in Cooperation and Competition: Antecedents and Consequences of Self-Orientation.” In R. Slavin et al., eds. Learning to Cooperate, Cooperating to Learn: 17-65.

Prentice, R. “Consultative Learning: The Humanization of Education.” hi Fl. Nikjoo, ed, Trends in Bahá’í Education: 191-200.

Rabbani, Rúhíyyih. The Priceless Pearl. London: Bahá’í Publishing Trust, 1969.

Rosenfeld, R. B., and M. H. Winger-Bearskin. "Principles of Consultation Applied to the Process of Innovation in a Corporate Environment.” The Journal of Bahá'í Studies 3:1 (1990): 31-48.

Schmuck, R. "Learning to Cooperate, Cooperating to Learn: Basic Concepts.” In R. Slavin et al., eds. Learning to Cooperate, Cooperating to Learn: 1-4.

Sharan, S., ed. Cooperative Learning: Theory and Practice. New York: Praeger, 1990.

Slavin, R. “An Introduction to Cooperative Learning Research.” In R. Slavin et al., eds. Learning to Cooperate, Cooperating to Learn: 5-15. 
. Cooperative Learning: Research, Theory, and Practice. Englewood Cliffs, NJ: Prentice Hall, 1990.

Slavin, R., et al., eds. Learning to Cooperate, Cooperating to Learn. New York: Plenum Press, 1985.

Snow, M. “Instructional Methodology in Immersion Foreign Language Education.” In A. M. Padilla, H. H. Fairchild, and C. M. Valadez, eds. Foreign Language Education: Issues and Strategies. Newbury Park, CA: Sage Publications, 1990: 156-71.

Solomon, D., et al. "Creating Caring School and Classroom Communities for All Students.” To appear as a chapter in W. C. Stainback and S. B. Stainback, eds. Restructuring for Heterogeneity: An Administrative Handbook for Creating Schools for Everyone. Baltimore: Paul H. Brookes, forthcoming.

Solomon, D., et al. “A Program to Promote Interpersonal Consideration arid Cooperation in Children.” In R. Slavin, et al., eds. Learning to Cooperate. Cooperating to Learn: 371-401.

Solomon, D., et al. “Cooperative Learning as Part of a Comprehensive Classroom Program Designed to Promote Prosocial Development.” In S. Sharan, ed. Cooperative Learning: Theory and Practice. New York: Praeger, 1990: 231-60.

Stainback, W. C., and S. B. Stainback, eds. Restructuring for Heterogeneity: An Administrative Handbook for Creating Schools for Everyone. Baltimore: Paul H. Brookes, forthcoming.

Stone, J. M. Cooperative Learning and Language Arts: A Multi-Structural Approach. San Juan Capistrano, CA: Resources for Teachers, 1991.

Universal House of Justice, The. Individual Rights and Freedoms in the World Order of Bahá'u'lláh: To the Followers of Bahá'u'lláh in the United States of America. Wilmette, IL: Bahá'í Publishing Trust, 1989.

- Letter to the National Spiritual Assembly of Italy, 19 November 1974. In H. H. Vick. Social and Economic Development: A Bahá'í Approach. Oxford Ronald, 1989: 38.

- The Promise of World Peace. Also published as "To the Peoples of the World: A Bahá'i Statement on Peace.” Bahá'í Studies 14. Ottawa: Association for Bahá'í Studies, 1986.

—. Wellspring of Guidance. Messages 1963-1968. Wilmette, IL: Bahá'í Publishing Trust, 1969.

Waite, Stephen H. A Charter for Bahá'í Schools. Department of Social and Development and Education of the National Spiritual Assembly of the Bahá'ís of India, 1989.

Watson, M., et al. “The Child Development Project: Combining Traditional and Developmental Approaches to Values Education.” In L. P. Nucci, ed. Moral Development and Character Education: A Dialogue.

Berkeley, CA: McCutchan, 1989: 51-92. 